was persuaded to stay on for another term. Mr. Mohamed Afifi (Morocco) was appointed assistant to the honorary secretary. The honorary treasurer is Dr. Vladimir Vaclavek (Czechoslovakia). The honorary life members remain M. Jean Painlevé (France) and Mr. Jan Korngold (Poland). The editorin-chief of Scientific Film, the journal of the Association, is Mr. Maurice Goldsmith (Great Britain).

The liaison officer of the Association with the International Science Film Library is Mr. Luc
Haesaerts (Belgium); the chairman of the Television Study Commission is Mr. John Maddison, and of the Unesco-International Scientific Film Association Science Films Commission, Mr. Bernard Chibnall (Great Britain). The chairmen of the Standing Committees are: Research, Dr. R. Robineaux (France); Popular Science, Mr. V. Tosi (Italy); and Education, Prof. J. Jacoby (Poland). Next year's Congress is likely to be held in Rabat, Morocco. Maurice Goldsmith

\title{
A BRITISH SOURCE OF NATURAL GAS
}

$\mathrm{T}$ HAT in Britain there should be in daily use a supply of natural gas may well surprise many well-informed people. Indeed, it was in 1938 that two discoveries of natural gas in Britain were made, one at Cousland, south-east of Edinburgh, and the other west of Whitby at Eskdale. At that time no commercial outlet existed for these potential supplies and the wells were sealed off for eventual future use. The Cousland discovery has been harnessed by the Scottish Gas Board for the use of Musselburgh, where after being suitably treated it forms part of the gas supply.

Now there comes the news of interest more particularly to the inhabitants of the Whitby district of tho actual utilization of the gas from the Eskdale area. The wells are situated in moorland of much natural beauty; but there is no fear that the amenities of that fair land will be impaired by tho small surface equipment that marks the source of a sufficient supply of gas to serve a new but sole production unit in the Whitby Gas Works.

Two wells, of some eleven that have been drilled, have proved to be gas producers. These wells have a closed pressure approximating to $2,000 \mathrm{lb}$. per sq. in., and draw their gas from limestone layers, rospectively 4,196 and $4,807 \mathrm{ft}$. below ground-level. It was only in April this year that these wells were re-opened and now the laying of a 3 -in. pipe-line has been completed. Further, in order to produce from the natural gas, which contains 93-94 per cent of methane and has a calorific value of 1,000 B.T.U. per cu. ft., a final gas for public distribution of 500 B.T.Y. per cu. ft., a conversion plant has also been installed.

The conversion process of the gas is known as a reforming process. It consists essentially of the reaction of the natural gas with steam to produce hydrogen and carbon monoxide. It is carried out in special heat-resisting steel tubes which are heated to about $1,100^{\circ} \mathrm{C}$. and contain a nickel catalyst. It is then enriched with some cold natural gas, and flue gas from the tube-furnace, fired by natural gas. This is necessary to adjust it to the correct calorific value and density for public distribution.

It is also interesting to note that the gas is of such a freedom from sulphur impurity that in order to ensure that gas supplied to the town should have a distinct odour, equipment for the purpose has been installed, employing tetrahydrothiophen as odorant.

The two wells available have a combined flow-rate up to $4 \cdot 5 \mathrm{~m}$. cu. ft. per day. Three reformer units have been provided, each having a daily capacity of $625,000 \mathrm{cu}$. ft.

The plant has been put to work in recent weeks, and the venture is so new that the performance tests have yet to be carried out. R. J. SARJANT

\section{THE LIBRARY IN SCIENCE AND TECHNOLOGY}

$\mathrm{O}^{\mathrm{r}}$ the papers of scientific interest presented at the annual conference of the Library Association at Scarborough, September 12-16, that of Dr. D. J. Urquhart describing the planning of the National Lending Library for Science and Technology and the ideas and motives behind it is undoubtedly the most irnportant, but some of the other papers should not be overlooked by the scientist and technologist. In his presidential address on September 13, Mr. B. S. Page, librarian of the Brotherton Library, University of Leeds, discussed librarianship as he saw it practised in English universities of the twentieth century, and more particularly the research side of such work. Research, he suggested, in fact determined the extent, and very largely the character, of the collections and greatly influenced every aspect of the work of a university librarian, and Mr. Page emphasized, first, that the librarian and his readers were members of the same university community, with all it implied, and secondly, that the reader regarded the library less as an amenity than as a necessity; his use of it was regular and professional ; normally his work could not proceed without it, and how it operated made an immense difference to the reader's peace of mind and perhaps his hopes for the future. From this Mr. Page argued that because selection had to make the most of very limited resources, buying must be largely related to specific interests which have to be known and understood by the library staff, while at the same time important works had to be acquired for future needs and a closo watch kept over special collections and special emphases in general colloctions. The librarian must be thoroughly equipped to make the most of the potential cooperation of the experts in the teaching departments surrounding him and, pointing out that a university 
library is being assembled for generations of scholars, Mr. Page claimed that the quality of library development could do much to make or mar the future welfare and importance of the university.

Mr. Page again emphasized the importance of the personal qualities of the librarian in referring to problems of cataloguing and classification, urging that the schemes to be adopted should not be such as to cause irritation or hindrance to the reader, and, besides putting in a word for the value of browsing among the open shelves as a source of inspiration and insight, he pleaded for imagination as well as knowledge on the part of the librarian and bis staff. Techniques, he insisted, were means to an end and the librarian must be prepared to meet his readers on their own ground and to speak their language. Moreover, besides professional techniques, he needed specialized knowledge, experience of research, and the enthusiasm which came of such specialization. The ideals of personal acquaintance with books, personal help to readers, and unselfish devotion to the advancement of knowledge were as valid as when Henry Bradshaw formulated them in 1882.

Mr. M. C. Pottinger's account of libraries in the Soviet Union was of general rather than scientific interest. He commented on the generous provision of reading or study rooms as a common feature of Russian Libraries, and on the claim of the Bibliographical Reference Department, with a staff of about 100, at the Lenin State Library, Moscow, to supply bibliographies on any topic. In a subsequent paper to the conference, Mr. R. G. Surridge referred to the lack of attention to bibliography in libraries in Britain and suggested that a new well-designed Chaucer House, in co-operation with the National Central Library, should provide a comprehensive Bibliographical Department.

Miss L. V. Paulin's paper on "Technical Library Services" described some of the co-operative schemes that had been set up in Manchester, Sheffield, Liverpool and elsewhere in a field where any general co-ordinated policy was completely lacking. Most of the schemes, however, were for large eities where many highly developed libraries were already available and the greatest need was in the counties. The rapid development of adequate libraries in technical colleges provided an opportunity for remedying this position, and Miss Paulin quoted from the Ministry of Education's report on Technical Education of 1956 to indicate the opportunity that existed to build up a really integrated technical library service between the public library and the technical college. The most rural county to tackle the problem so far was Herefordshire, where a County Technical Library service, based on the Herefordshire Technical College, would begin in January 1961, but Northumberland and Durham were already co-operating with a Newcastle scheme, and Middlesex with a West London scheme. The Northamptonshire County Technical Library Service, started in July 1957 and based at Corby Technical College, was already experiencing a large potential demand, while in Hertfordshire a technical library and information service was based on technical colleges and completely integrated with the County Library. This pilot scheme was described in some detail by Miss Paulin, who stressed that such services in the country as a whole must be based on co-operation. The main requirements were receptiveness of mind among members of industrial and com- mercial firms and an awareness of the value of up-to-date information; a comprehensive, easily accessible collection of books, pamphlets and periodicals in the care of knowledgeable librarians, with the occasional assistance of technologists in dealing with inquiries; and equipment for documentary reproduction.

A following paper, by Dr. H. Coblans, on "International and Local Information", attempted to assess the present structure and likely trends of scientific and technical information services from a survey of a few characteristic countries, such as Switzerland, West Germany, France and Poland. On the international plane there were now signs of a more generous policy towards co-operation, and the International Atomic Energy Agency has created a Division of Scientific and Technical Information which publishes a number of bibliographical tools to implement the Agency's statutory responsibility to further the exchange of information among its member States. Urging caution as to the value of some of the new technical possibilities for transmission of information, such as 'Telex', which admittedly if imaginatively used could transform the effectiveness of information services, Dr. Coblans said that each country should endow and maintain a National Science Library adequately staffed to provide the rapid service that new techniques permit, while international governmental organizations must place their great resources of information fully at the disposal of the national centres. The technical advances, however, involved the obligation to re-think and re-shape some of the British principles of publication, bibliography, ab. stracting, copying and copyright and inter-library loan. Ultimately this should be done by international discussion and agreement, but national associations, such as the Library Association and the Association of Special Libraries and Information Bureaux, must take the first step.

Dr. Urquhart said that the site of 60 acres at Boston Spa, where it was hoped the first buildings of the new National Lending Library for Science and Technology would be ready at the end of this year, allowed for considerable elasticity in planning, and the present aim was to provide the practitioner in science or technology with all the current literature of the world he might need. They were only trying to obtain the older literature where they had evidence of demand, or where it did not exist in a readily accessible collection, but they were prepared to accept and make available scientific and technological literature of any age. The Library should become fully operational in September 1962, and only then could the extent to which it would be able to meet the demand on its services be measured; at present, however, its collection could provide about 90 per cent of the Russian literature and translation which are requested. Staff was being selected so that collectively it could understand not only the language of science but also the increasing number of national languages in which seience was written. It was hoped to transfer the 1,000 tons of literature from London to Yorkshire without closing any service, and although it was expected that some requests would go to the Science Museum Library which should have been sent to Boston Spa, the handling of such requests would be simplified by use of the same type of forms.

Dr. Urquhart said it was not intended to start any large technical information service, but rather to 
assist existing services where possible by directing attention to any literature in their fields of which they might otherwise be unaware, though it would be part of the new Library's responsibility to see that attention was given to any gaps in the technical information services which might develop : one such gap had emerged with regard to Russian translations, on which the Library was now spending more than $£ 100,000$. Dealing more particularly with the relations of the new Library to the rest of the library system, Dr. Urquhart said that in the near future some of the larger libraries and the special libraries would be invited to notify the Library systematically about new serials or conference proceedings which they decided not to acquire, but for which they might have some future need. On the collecting side they would invite all libraries to let them know of publications in the National Library's field for which they received an embarrassing volume of requests for inter-library loans. By collecting such material the new Library would help the inter-library loan arrangements to work more smoothly, but at present the potential loan demand on the new Library seemed to be increasing, and Dr. Urquhart thought the tendency was likely to continue, particularly because the new Library's loan service would be faster than the existing services. Accordingly, they were very interested in efforts to tune up the inter-library loan system. $\mathrm{He}$ thought there was no fundamental reason to prevent evolution of a national inter-library loan form using the prepaid flat-rate system for postage.

Irrespective of its effect on inter-library loan procedure, the existence of the National Lending Library for Science and Technology might well have more profound effects, such as producing a demand for a national lending library for the humanities, possibly based on the National Central Library. Dr. Urquhart, however, left this for future consideration and referred them to the relations of the new Library with local libraries, emphasizing that the potentialities of the comprehensive collection of scientific literature at Boston Spa could not be fully utilized unless the potential users in each locality could discover what they wanted to read, that is, unless guides to the literature of science were available locally. We needed a form of co-operation in which local libraries would assist potential users to find out what they wanted to read, and the National Lending Library would, if necessary, supply this literature. It was intended that such co-operation would be based on the idea that each partner in the scheme would pay his own expenses, and they had recently written about this idea to every local authority and technical college in the United Kingdom. At present, however, standards of technical library service available to the public in many areas were not high: a standard which technologists might criticize as inadequate was attained by only eighteen public libraries and seventeen technical college libraries, and in oonsequence the National Library was building up some sets of bibliographical tools to lend to libraries which are considering developing their bibliographical collections. They had also been thinking about relations with the public libraries and about the training of librarians, and in conclusion Dr. Urquhart urged that future policy must be based on the scientific analysis of the facts.

\section{CHEMICAL DOCUMENTATION}

\begin{abstract}
CHEMISTS nowadays are increasingly eager to 1 receive new chemical matter "hot from the press" but many find it impossible to cope quickly with the mass of information contained in the many traditional journals appearing almost hourly. A few years ago the Chemical Society made a great effort to save the chemist's time by introducing a monthly publication, Current Chemical Papers, in which some hundreds of selected titles of papers taken from more than four hundred chemical journals of note were set down under their appropriate sections. The undoubted success of Current Chemical Papers has led the American Chemical Society to copy the essentials of the scheme with the publication on an experimental basis of Chemical Titles*.

The major difference is that Chemical Titles is produced by machines and thus may claim a potential wider coverage and give greater detail.

The titles of some five hundred journals, translated where necessary, are punched on to I.B.M. cards together with the authors' names and journal references and are then fed to computers. Within two hours the new journal appears containing three parts. The first part consists of a permuted title index in which key-words from each title have been arranged alphabetically down the centre line of the column. The second part consists of an alphabetical list of

* Chemical Titles. No. 1, April 1960, 101 pp.; No. 2, May 1960 89 pp. Chem. Abs. Service. American Chemical Society
\end{abstract}

first listed authors together with the titles of their current papers published in the selected journals. The third part (in No. 2 only) gives an index of authors other than the first listed for each paper along with the code reference for the paper.

In addition to the key-word, each horizontal line contains as much of the remainder of the title as the machine's programme permits and thus assists in selection of significant titles.

The system is used by scanning vertically the alphabetical key-word list and then, when interest is seized, by reading the horizontal text. When more information is required the reference code on the right-hand side of the entry is noted and located in the alphabetical author index.

The whole system of making the reference code, etc., and for using the system are described fully in the introduction. It is a very clever and easily understood system which appears to work.

The contents of some 550 journals have been dealt with, and it is planned to make a semi-monthly issue of $2,000-3,000$ titles.

A good many improvements have been made in No. 2, especially in editing, and more will be made as experiments proceed and as suggestions and criticisms are received. The printing will need to be much better and larger if possible.

The publication fully justifies the claim that it increases "current awareness". It will probably be of 